\title{
COVID-19 Pandemic in Yemen
}

*Saleh Musaed Mohammed Al-Subari ${ }^{1}$, Mohammad Saleem ${ }^{1}$, Sitaram Khadka ${ }^{1}$, Nagd Mohammed Ahmed Mahmood ${ }^{1}$, Talal M. Ziad Alhouzani ${ }^{1}$, Dhan Bahadur Shrestha ${ }^{2}$

${ }^{1}$ Department of Pharmacology, Punjab University College of Pharmacy, University of the Punjab, Lahore-54000, Pakistan;

${ }^{2}$ Mangalbare Hospital, Morang, Nepal

*Corresponding Author: Saleh Musaed Mohammed Al-Subari E-mail: salehmusaed5@gmail.com

\begin{abstract}
COVID-19, a global pandemic, has threatened the whole world with its devastating nature. Though, initially it has affected the developed countries, the countries in low- and middle-income category also are not spared. Yemen is a country with low-income economy and has been in an ongoing civil war. The first case of COVID-19 was reported on 10th April 2020 and there have been a total of 1619 cases along with 447 total deaths as of 21 st July 2020 . The preventive measures such as lockdown, social distancing, and personal hygiene are practiced, however there is still lack of adequate resources for efficient healthcare facilities. No drugs and vaccines are approved to fully rely on for the treatment of COVID-19, therefore the concept of "do not take the virus and do not give the virus" with different approaches of preventive aspects through hand-washing, social distancing, wearing masks and gloves, and making people aware in mass utilizing audio-visual media are helpful. Aids from different agencies and collaborative efforts of all the stakeholders are in need for the containment of COVID-19 cases in Yemen. By strengthening and increasing healthcare set-ups and resources, preparation of management guidelines by the government and mobilizing such resources to different parts for awareness, adequate reverse transcription-polymerase chain reaction (RT-PCR) tests, contact tracing, and safe quarantine and isolation services are essential.
\end{abstract}

Keywords: Coronavirus; COVID-19; Disease outbreaks; Health resources; Pandemics; Yemen

\begin{tabular}{|c|c|c|}
\hline \multicolumn{2}{|c|}{ Access this article Online } & Article Info. \\
\hline Quick Response Code & Website: & How to cite this article in Vancouver Style? \\
\hline & www.jkahs.org.np & $\begin{array}{l}\text { Al-Subari SMMA-S, Khadka S, Mahmood NMA, } \\
\text { Alhouzani TMZ, Shrestha D. COVID-19 Tackling in } \\
\text { Yemen: An Overview of Scenario. .Journal of Karnali } \\
\text { Academy of Health Sciences 2020;3(2): 159-163 }\end{array}$ \\
\hline \& Vie & $\begin{array}{l}\text { DOI: } \\
\text { https://doi.org/10.3126/ } \\
\text { jkahs.v3i2.31383 }\end{array}$ & $\begin{array}{ll}\text { Received } & : 8 \text { July } 2020 \\
\text { Accepted } & : 16 \text { August } 2020 \\
\text { Published Online } & : 17 \text { August } 2020 \\
& \\
\text { Conflict of Interest } & : \text { None } \\
\text { Source of Support } & : \text { None }\end{array}$ \\
\hline
\end{tabular}




\section{INTRODUCTION}

In the late December 2019, a cluster of pneumonialike outbreaks was reported from Wuhan, China. The disease was named coronavirus disease-19 (COVID-19) and the causative agent identified was the novel coronavirus and named severe acute respiratory syndrome coronavirus-2 (SARS-CoV-2). ${ }^{1}$ The disease spread very fast around the globe, therefore WHO declared it as a global pandemic in $11^{\text {th }}$ March 2020. ${ }^{2}$ The disease remained the global health threat until now. COVID-19 is presented with the symptoms of respiratory ailments and even death in severe cases. ${ }^{1}$

There is no fully proven therapy for this disease. Therefore, different types of supportive cares along with potential treatment options are being practiced in different places based on WHO guideline. ${ }^{3}$ This ailment has affected the whole world with more than 14 million cases and more than 600 thousand death tolls until $21^{\text {st }}$ July $2020 .{ }^{4}$ Though very few countries are being able to contain the disease effectively, most of the countries around the world are in worse condition as far as the management of COVID-19 is concerned. Low-and middle income countries (LMICs) like Yemen are in vulnerable state in case of large-scale outbreak of COVID-19.

\section{YEMEN IN THE WORLD}

Yemen, a landlocked country with low-income economy, shares open border with Saudi Arabia and

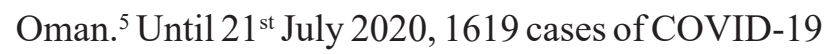
are reported in Yemen. ${ }^{6,7}$ The health systems in Yemen comprises of four levels of facilities; health units, health centers, district or governorate hospitals, and referral hospitals. ${ }^{8}$ There are approximately 4207 public health facilities including 243 hospitals. ${ }^{9}$ The poverty and ongoing civil war since 2015 has affected the country very badly. Many infrastructures related to healthcare are in fragile condition and hygiene and sanitation systems are very poor. Almost half of the population is deprived of safe drinking water. Acute malnutrition in pregnant women and children is another challenge to the nation. ${ }^{10}$ Basic healthcare facility is out of reach to about 16.4 million people. ${ }^{11}$ The communicable disease treatment facility and maternal and immunization services are available in only $43 \%$ and $35 \%$ of functional health facilities respectively. ${ }^{8}$ This has provided the room for the spread of other infections along with COVID-19. The health care system in Yemen, that is why, is not capable to tackle if the outbreak occurs like in other countries. The massive shortage of medicines and related items and the vulnerable healthcare status of the nation makes the healthcare system largely dependent on the World Health Organization (WHO) and its humanitarian partners' aids.

\section{Covid-19 Status and Considerable Risks in Yemen}

The landlocked status and an open border system has put Yemen in a high risk for COVID-19 spread. The first confirmed case of coronavirus was reported in $10^{\text {th }}$ April 2020 in Hadramout Province in a 60 -years old patient. ${ }^{12}$ There are total 1619 cases with 447 deaths due to COVID-19 in Yemen as of $21^{\text {st }}$ July $2020 .^{7}$ In Yemen, total cases and deaths trend curves are getting flat since late June (Figure 1) as reporting of new cases and deaths has been decreased (Figure 2). The transmission phase is stated as community transmission by the WHO until now. ${ }^{13}$ Though the cases of COVID-19 are not so high, this is sufficient to alert the healthcare system of the country as the system is not up to the standard like that of developed countries. Only six polymerase chain reaction (PCR) machines available all over the nation are too less to cover the whole 28.5 million population. ${ }^{14}$ The aggressive use of rapid tests has added up more burden in healthcare cost and overall system. The national laboratory system is not up to the standard and a few central laboratories such as The National Central Public Health Laboratory in Sana'a along with its four divisions in Aden, Taiz, Hadramout, and Hodeidah governorates are operative. ${ }^{8}$ There are only 500 ventilators in the country. ${ }^{15}$ The country is at the high risk of outbreak, given the unstable situation due to armed conflicts that have already resulted destructions of lives and infrastructure including health care systems. The simultaneous outbreaks of infectious diseases such as cholera, diphtheria, dengue fever, and tuberculosis along with COVID-19 have also added burden. ${ }^{6}$ 


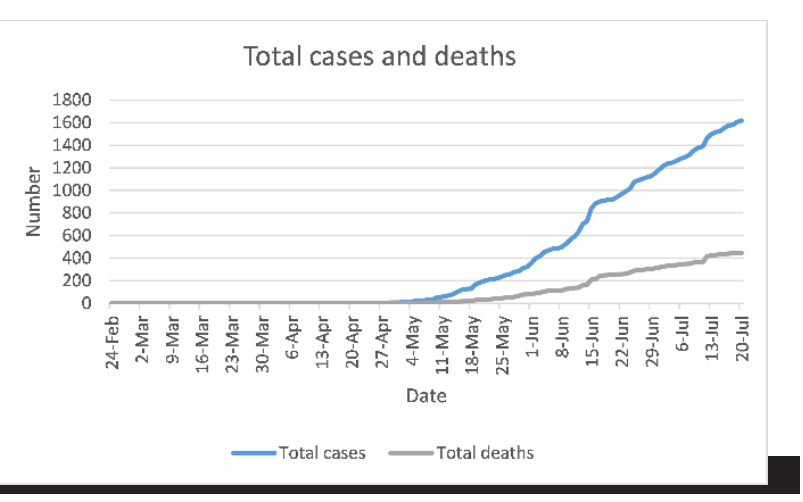

Figure 1: Trend of total cases and total death since first case reported

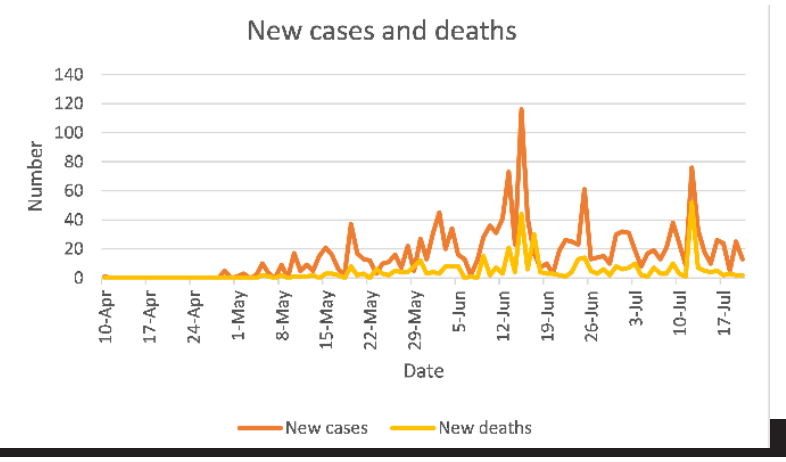

Figure 2: Daily new cases and deaths reported in Yemen since the first case reported

The government's conclusion to set up a national COVID-19 taskforce and response plan is a good initiative for its management. The electronic disease early warning system adopted for the effective realtime disease surveillance makes up for almost 37\% of the health facilities in Yemen. ${ }^{10}$ However, the deficiency of technical experts essential for field work is still there. The fragmented government and fragile healthcare system are ill prepared to effectuate international health regulations standards. Though the country is in lockdown and schools and universities are still closed, there is lack of secured check points with technical capacity and isolation at entry points. ${ }^{10}$ Even with the inadequate personal protective equipment (PPE), oxygen supply, and clean water, only half of health facilities are operative. ${ }^{16}$ Yemen is now confronting a triple catastrophe of conflict, coronavirus and cratering economy. Millions of children are deprived of vaccination against polio, diphtheria, cholera, and almost half millions of women of child-bearing age are not getting vaccination against tetanus as the immunization program has been halted. ${ }^{17}$
Hence, the assistance from different agencies and specific plans are in need for effective control. Emphasis should be given to proper medical supply chain management such as of emergency medicines, masks, gloves, PPE, and disinfectants as well as infrastructure development such as building emergency hospitals with adequate intensive care unit (ICU) beds and ventilators. The fast and effective laboratory testing service should be implemented in quarantine and isolation areas. ${ }^{18}$ The WHO is coordinating the humanitarian response to cater health issues with Yemen's Ministry of Health and 20 partner humanitarian organizations in Yemen, including the International Committee of the Red Cross (ICRC) and Médecins Sans Frontières (MSF). ${ }^{19}$ The United Nations (UN) and related organizations have pleaded for COVID-19 funding that covers facilities on healthcare resources for COVID-19 management while continuing to support millions in crisis. ${ }^{16}$ Saudi Arabia has also hosted a conference on donor pledging in coordination with the UN aiming at addressing the humanitarian needs in Yemen. ${ }^{20}$ The WHO is assisting by different ways in COVID-19 management in Yemen by making well-equipped isolation centers in existing healthcare centers and in temporary hospitals. ${ }^{21}$ In such crisis amid COVID-19, the Government of Germany is also providing support in emergency food aid, healthcare, water and sanitation, and protective measures. ${ }^{22}$ As the country is at the most severe humanitarian crises in the world where $80 \%$ of the Yemeni population are dependent on humanitarian aid, the focus on life-saving measures can be of value.

There is a strong need of compliance of people with the preventive measures such as lockdown, social distancing, and personal hygiene. ${ }^{23}$ The peoples' irresponsibility to maintain lockdown and social distancing in many cases; social stigmatization towards health care providers, suspected and confirmed COVID-19 cases, and recovered cases as well; are increasing psychological burden to the society $^{24,25}$. The negative impact on human rights due to COVID-19 lockdown in social, economic, and mental status is on the rise in LMICs like Yemen. The lack of healthcare equipment, health resources, 
less availability of health care set-ups, irregularity in salaries, and fragmented governing bodies are creating difficulties for more than 50,000 healthcare human resources in Yemen amid COVID-19 pandemic. ${ }^{17}$ This indicates a problem in adequately handling the outbreak.

\section{CONCLUSION}

Unavailability of proven therapy, chaotic scenario of case load and mortality, and physical and mental impactrelated to coronavirus pandemic has challenged the whole world. The LMICs like Yemen, which is under the wrath of long ongoing civil wars and poverty, is definitely in a vulnerable state. Effective preventive measures like social distancing, hand washing, awareness campaigns through audio-visual media are mandatory. Strengthening and increasing healthcare set-ups and services with ICU facilities, adequate RT-PCR tests, contact tracing strategies and safe quarantine and isolation services are the effective approaches. The mental health impact of disease is another burden in such nations. Though the cases till date are not high in number, the probable risk should not be underestimated and containment strategies are to be followed seriously. The active participation of government with a special task force to make a standard guidelines for COVID-19 management and to safeguard the frontline professionals with proper resources delivery at all levels is mandatory. It is timely to garner collaborative efforts of relevant agencies to mitigate the damages of the ongoing pandemic.

\section{REFERENCES}

1. Khadka, S., Hashmi, F.K. \& Usman M. Preventing COVID-19 in low- and middleincome countries. Drugs Ther Perspect. 2020;36(6):250-2. https://doi.org/10.1007/ s40267-020-00728-8. [Google Scholar] [PubMed]

2. Jamie Ducharme. World Health Organization Declares COVID-19 a "Pandemic." Here's What That Means. TIME. 2020. Accessed 21 Jul 2020.[Link]
3. WHO. Clinical management of severe acute respiratory infection (SARI) when COVID-19 disease is suspected. 2020. Accessed $21 \mathrm{Jul}$ 2020. [Link]

4. WHO. Coronavirus (COVID-19).2020. https:// covid19.who.int/. Accessed 21 Jul 2020. [Link]

5. The World Bank Group. Data. 2020. Accessed $21 \mathrm{Jul}$ 2020. [Link]

6. BBC News. Yemen "faces nightmare" as first coronavirus case confirmed. 2020 Apr 10. Accessed 21 Jul 2020. [Link]

7. WHO. Yemen. 2020. Accessed 21 Jul 2020. [Link]

8. Dureab F, Al-Sakkaf M, Ismail $\mathrm{O}$ et al. Diphtheria outbreak in Yemen: the impact of conflict on a fragile health system. Confl Heal. 2019;13(19). https://doi.org/10.1186/s13031019-0204-2. [Google Scholar][PubMed]

9. Yemen National Health and Demographic Survey 2013. Republic of Yemen, Ministry of Public Health and Population and Central Statistical Organization. Published 2015. Accessed 21 Jul 2020. [Link]

10. Dureab F, Al-Awlaqi S JA. COVID-19 in Yemen: preparedness measures in a fragile state. Lancet Public Heal. 2020. https://doi. org/10.1016/S2468-2667(20)30101-8. [Google Scholar][PubMed]

11. Humanitarian Overview. Yemen. Published 2018. Accessed 21 Jul 2020. [Link]

12. AlJazeera.Yemen confirms first coronavirus case, braces for outbreak. 2020 Apr 10. Accessed 21 Jul 2020. [Link]

13. WHO. Coronavirus disease (COVID-19) Situation Report - 168. 2020. Accessed 21 Jul 2020. [Link]

14. Yemen has only 6 corona devices, despite the outbreak. Yemen; 2020. Accessed 21 Jul 2020. [Link]

15. BBC News. Coronavirus: Surge in deaths reported in southern Yemen. 2020 May 14. Accessed 21 Jul 2020. [Link] 
16. Yemen: Humanitarians seeking $\$ 2.41$ billion to keep aid flowing amid COVID-19 pandemic. UN News. 2020. Accessed 07 Jul 2020. [Link]

17. UNICEF. Remarks by UNICEF Executive Director Henrietta Fore at joint press briefing on the humanitarian situation in Yemen. 2020. Accessed 07 Jul 2020. [Link]

18. Daw M. Corona virus infection in Syria, Libya and Yemen; an alarming devastating threat. Trav Med Infect Dis. 2020;(101652). https:// doi.org/10.1016/j.tmaid.2020.101652. [Google Scholar][PubMed]

19. Health system in Yemen close to collapse. Bull World Health Organ. 2015;93(10):6701. https://doi.org/10.2471/BLT.15.021015. [Google Scholar][ubMed]

20. Devi S. Fears of "highly catastrophic" COVID-19 spread in Yemen. Lancet. 2020;395:10238:1683. https://doi.org/10.1016/ S0140-6736(20)31235-6. [Google Scholar] [PubMed]
21. WHO. Grimley N. Coronavirus: Yemen medics braced for "unspeakable" crisis. 2020. . Accessed 21 Jul 2020. [Link]

22. The fight against COVID-19: helping save lives in Yemen. OCHA Services. 2020. Accessed 21 Jul 2020. [Link]

23. Sajed AN, Amgain K. Corona Virus Disease (COVID-19) Outbreak and the Strategy for Prevention. Eur J Med Sci. 2020;2(1):1-4. https://doi.org/10.46405/ejms.v2i1.38. [Google Scholar]

24. Budhathoki P, Shrestha DB, Khadka S, Giri S. COVID-19 Status in Nepal and the Way Forward. Eur J Med Sci. 2020;2(2). https://doi. org/10.46405/ejms.v2i2.75. [Google Scholar]

25. Chalise A, Paudel S. Mental Health Concern during COVID-19 Pandemic in Nepal. Eur J Med Sci. 2020;2(2):39-44. https://doi. org/10.46405/ejms.v2i2.87. [Google Scholar] 